\title{
Effect of barite and gas oil drilling fluid additives on the reservoir rock characteristics
}

\author{
Dhorgham Skban Ibrahim $^{1} \cdot$ Nagham Amer Sami $^{1} \cdot$ N. Balasubramanian ${ }^{2}$
}

Received: 12 June 2015/Accepted: 22 May 2016/Published online: 25 June 2016

(C) The Author(s) 2016. This article is published with open access at Springerlink.com

\begin{abstract}
This research presents a study of the effect of drilling fluid on the reservoir rock properties. The interactions between the clay minerals existing in the formations and the drilling fluids have been studied. Two types of drilling fluids, which are water-based ferrochrome lignosulfonate base mud and lime mud, were prepared for the study. About 100 core plugs were prepared from seven oil wells of Zubair Formation from depths of over (3000) m. The core plugs were cut, cleaned, dried, and then subjected to petrophysical tests, which are permeability, saturation, $\mathrm{X}$-ray diffraction, and the petrographical analyses. Clay minerals like kaolinite, illite, and montmorillonite were found in the core samples. The static immersion test shows that the clay minerals reacted with the drilling fluids and created swelling and spalling in the core samples and changed the original petrophysical rock properties. Different concentrations of gas oil and barite were added to improve the properties of the used drilling fluids and to decrease their negative impact on the petrophysical rock properties. A comparison is made between the permeability and water saturation before and after exposure to the drilling fluids. The percentage change in permeability and water saturation is calculated. The results showed that the additives to the drilling fluids reduced the formations damage. Finally, the study indicates that the major formation damage in southern Iraqi oil fields is induced by mechanical and chemical mechanizes.
\end{abstract}

N. Balasubramanian nbsbala@annauniv.edu

1 Department of Petroleum Engineering, College of Engineering, University of Baghdad, Baghdad, Iraq

2 Department of Chemical Engineering, AC Tech Campus, Anna University, Chennai 600025, India
Keywords Formation damage $\cdot$ Drilling fluid $\cdot$ Core sample $\cdot$ Petrophysical properties $\cdot$ Clay minerals

\section{Introduction}

During oil well drilling operations the formations rock exposed to drilling fluids, which may impair its productive capacity. This reduction in rock productivity is termed formation damage. Damage ratio is the property after damage divided by the original undamaged property (Blkoor and Fattah 2013). For oil permeability, the damage ratio may range from 0.3 to 1.0 depending on the type of the mud filter loss and type of core material. Therefore, it is necessary to select the proper drilling fluid, which have the best functions of drilling operations, and achieve minimum formation damage.

Although there are several functions of drilling fluids in the drilling engineering like cooling and lubrication of bit and drilling string, bottom hole cleaning and cutting transportation, and control of subsurface pressure (Sönmez et al. 2013), drilling fluids have some of the disadvantages that related to formation damage. The selection of suitable drilling fluid for a given reservoir may be critical (AlHitti et al. 2005). Many researchers proved the effects of drilling fluids on petrophysical properties due to the selection of unsuitable mud. Selection of the proper drillin-fluid (DIF) composition was considered key for minimizing drilling problems and obtaining desired productivity levels (Hodge et al. 1997).

Many studies have dealt with the formation damage caused by drilling fluids, which is an interesting interdisciplinary subject that attracts many researchers. Ventresca et al. (1995) quantified the magnitude of the damage caused 
to the reservoir by inverted oil muds and selected chemical system, which is able to reduce this damage. Standard Hassler permeameter was used to determine the damage mechanism. Longeron et al. (1995) studied the formation damage induced by drilling muds in oil-bearing formations. This approach includes characterization of mud properties and filtration tests on long core samples $(40 \mathrm{~cm})$. The damage caused by filtrate penetration depends on the effectiveness of fluid loss control. The filtrate penetration may range from a few inches to several feet. This process is called invasion process, and the damaged zone is called the invaded zone or the skin zone. Hence, oil effective permeability in the skin zone will decrease and the saturation will change (Windarto et al. 2012). Warren et al. (2001) used air particles for minimizing formation impairment in the drilling fluid system. Air particles were used as the bridging particles to remedy formation damage. This treatment was applied in higher-pressure wells and gives low-density muds from (5.8) to (8.3) ppg. Falkowicz and Kapusta (2002) controlled formation damage by the biological method. He has formulated bacterial package to minimize skin damage when incubated in drilling mud. Experiments were conducted in a range of temperature $\left(30-60{ }^{\circ} \mathrm{C}\right)$. The results indicated the biological method could efficiently reduce formation damage caused by various polymers that were existing in drilling fluids, but this method can actively propagate at temperatures as low as $20^{\circ} \mathrm{C}$. Dabiri et al. (2013) explained the formation damage due to erosion of external filter cake. All the researchers were corroborated the effect of drilling fluids on the petrophysical properties during the drilling process and developed different treatment techniques to void the negative effects.

Four basic formation damage mechanisms are related to the drilling mud systems, these being (Bennion et al. 1995, 1997):

1. Damage caused by incompatibility of the drilling fluids with the reservoir rocks (e.g., clay particles hydration).

2. Damage resulting from the incompatibility of the drilling fluid with the formation fluids (e.g., formation of emulsions).

3. Damage due to the mud filter cake, which is not lifted off or bypassed in non-perforated completions.

4. Damage caused by invasion of the pores by fine solids contained in the mud.

This research deals with the effect of drilling fluid additions on the petrophysical rock properties and the minerals existing in the Zubair Formation. Zubair Formation is the most important formation in Iraq and produced oil and gas from a gross thickness of (150-250) $\mathrm{m}$ and a net thickness of (90-170) $\mathrm{m}$. The Zubair Formation consists of interbedded shales and porous and permeable sandstones (Al-Ameri et al. 2011). An increase in water saturation in the zone immediately around the wellbore would cause a loss in effective oil permeability. However, in such a system, much of this water may be removed through oil production which occurs in clean pay sand. If filtration occurs in unclean sands (sands which contain clay minerals), clay swelling or other mechanisms may cause losses in oil permeability, which cannot be overcome through oil production (Glenn et al. 1957). The objectives of this study are to determine the nature of the formation damage due to the use of drilling fluids, to evaluate the extent of damage resulting from drilling fluids and its effect on reservoir rock characteristics, and to formulate recommendations for materials and procedures to be used to prevent formation damage.

\section{Materials and methods}

\section{Drilling muds}

Drilling muds are prepared in such a manner that it resembles the muds that are used according to the daily mud report of the South Oil Company, Iraq. Tables 1 and 2 show the composition of water-based ferrochrome lignosulfonate mud (FCLS) and lime mud, while Tables 3 and 4 show the physical properties of drilling muds, respectively.

\section{Basic components of drilling muds}

Several components are used to docile the rheological properties of drilling muds as follows:

\section{Water}

Water is the most important substance involved in drilling fluid technology. It is usually readily available at relatively low cost. Among the unusual properties of water in comparison with other liquids are the highest surface tension, dielectric constant, heat of fusion, heat of vaporization, and the superior ability of water to dissolve different substances.

\section{Barite}

One of the important functions of drilling mud is the control of formation fluid pressure to prevent blowouts. The density of the mud must be raised at times to stabilize fragile formations. Barite (barium sulfate, $\mathrm{BaSO}_{4}$ ) contains $58.8 \%$ barium and has a specific gravity of (4.2-4.5). Commercial barite, which is usually impure, is of lower specific gravity because of the presence of other minerals such as quartz, chert, calcite, anhydrite, celestite, and various silicates. In addition, it usually contains several iron minerals, some of which may increase the average specific gravity of the product. Barite 
Table 1 Composition of FCLS drilling mud

\begin{tabular}{|c|c|c|c|c|c|}
\hline \multirow[t]{2}{*}{ Additive materials } & \multicolumn{5}{|c|}{ Sample no. } \\
\hline & 1 & 2 & 3 & 4 & 5 \\
\hline Water (ml) & 350 & 350 & 350 & 350 & 350 \\
\hline Bentonite $(\mathrm{lb} / \mathrm{bbl})$ & 22.5 & 22.5 & 22.5 & 22.5 & 22.5 \\
\hline Barite $(\mathrm{lb} / \mathrm{bbl})$ & 70 & 70 & 70 & 140 & 140 \\
\hline Lignite (lb/bbl) & 3 & 3 & 3 & 3 & 3 \\
\hline Ferrochrome lignosulfonate (lb/bbl) & 3 & 3 & 3 & 3 & 3 \\
\hline CMC (lb/bbl) & 2 & 2 & 2 & 2 & 2 \\
\hline Caustic soda $(\mathrm{lb} / \mathrm{bbl})$ & 0.7 & 0.7 & 0.7 & 0.7 & 0.7 \\
\hline Soda ash $(\mathrm{lb} / \mathrm{bbl})$ & 0.7 & 0.7 & 0.7 & 0.7 & 0.7 \\
\hline Gas oil (vol\%) & - & $5 \%$ & $10 \%$ & - & $5 \%$ \\
\hline
\end{tabular}

Table 2 Composition of lime drilling mud

\begin{tabular}{|c|c|c|c|c|c|}
\hline \multirow[t]{2}{*}{ Additive materials } & \multicolumn{5}{|c|}{ Sample no. } \\
\hline & 1 & 2 & 3 & 4 & 5 \\
\hline Water (ml) & 350 & 350 & 350 & 350 & 350 \\
\hline Bentonite (lb/bbl) & 22.5 & 22.5 & 22.5 & 22.5 & 22.5 \\
\hline Barite (lb/bbl) & 70 & 70 & 70 & 140 & 140 \\
\hline Lignite (lb/bbl) & 3 & 3 & 3 & 3 & 3 \\
\hline Lime (lb/bbl) & 5 & 5 & 5 & 5 & 5 \\
\hline CMC (lb/bbl) & 2 & 2 & 2 & 2 & 2 \\
\hline Caustic soda $(\mathrm{lb} / \mathrm{bbl})$ & 0.7 & 0.7 & 0.7 & 0.7 & 0.7 \\
\hline Soda ash (lb/bbl) & 0.7 & 0.7 & 0.7 & 0.7 & 0.7 \\
\hline Gas oil (vol\%) & - & $5 \%$ & $10 \%$ & - & $5 \%$ \\
\hline
\end{tabular}

Table 3 Characteristics of FCLS drilling mud

\begin{tabular}{|c|c|c|c|c|c|}
\hline \multirow[t]{2}{*}{ Property } & \multicolumn{5}{|c|}{ Sample no. } \\
\hline & 1 & 2 & 3 & 4 & 5 \\
\hline$\theta 300$ (rpm) & 24 & 31 & 42 & 28 & 46 \\
\hline$\theta 600$ (rpm) & 38 & 50 & 71 & 45 & 76 \\
\hline Yield point $\left(\mathrm{lb} / 100 \mathrm{ft}^{2}\right)$ & 10 & 12 & 13 & 11 & 16 \\
\hline Plastic viscosity (cp) & 14 & 19 & 29 & 17 & 30 \\
\hline Density (ppg) & 9.6 & 9.55 & 9.65 & 10.6 & 10.55 \\
\hline API fluid loss (cc) & 9.6 & 7.2 & 6.3 & 10.5 & 7.5 \\
\hline
\end{tabular}

virtually is insoluble in water and does not react with other components of the mud. It has been used to raise the density to $1.44 \mathrm{gm} / \mathrm{cc}$ to control the gas inflow and stop caving and in pulling off dry pipe (Darley and Gray 1988).

\section{Bentonite}

Bentonite is the only commercial clay, which is now used in significant amounts in freshwater muds. It has been defined as consisting of fine-grained clays that contain not less than (85\%) montmorillonite (Abdou et al. 2013). Bentonite is added to freshwater muds in order to:

1. Reduce water filtration into permeable formations.

2. Increase hole-cleaning capability.

3. Form a low permeable filter cake.

4. Promote hole stability in unconsolidated formations.

5. Prevent or overcome loss of circulation. 
Table 4 Characteristics of lime drilling mud

\begin{tabular}{|c|c|c|c|c|c|}
\hline \multirow[t]{2}{*}{ Property } & \multicolumn{5}{|c|}{ Sample no. } \\
\hline & 1 & 2 & 3 & 4 & 5 \\
\hline$\theta 300$ (rpm) & 8 & 10.5 & 12 & 13 & 15 \\
\hline$\theta 600(\mathrm{rpm})$ & 14 & 20 & 22.5 & 22 & 26 \\
\hline Yield point $\left(\mathrm{lb} / 100 \mathrm{ft}^{2}\right)$ & 2 & 1 & 1.5 & 4 & 4 \\
\hline Plastic viscosity (cp) & 6 & 9.5 & 10.5 & 9 & 11 \\
\hline Density (ppg) & 9.7 & 9.6 & 9.42 & 10.65 & 10.6 \\
\hline API fluid loss (cc) & 24 & 20 & 16.5 & 35 & 32 \\
\hline
\end{tabular}

\section{Carboxymethylcellulose (CMC)}

CMC is an anionic polymer and is adsorbed on clay particles. Filtration is sharply reduced by low concentrations of CMC, and thermal degradation of CMC is accelerated as the temperature approaches $300{ }^{\circ} \mathrm{F}$. Also, it is used for raising viscosity. The effectiveness of CMC in reducing filtration and raising viscosity decreases as salt concentration increases.

\section{Lignite}

Lignite is an organic thinner that serves water muds for filtration reduction, oil emulsification, and stabilization of properties against high-temperature effects. It is not used as a thinner for salty muds. It maintains stable filtration rates in drilling hot holes. A major application for lignite is in conjunction with chrome lignosulfonates for improving the filtration property and thermal stability of mud.

\section{Ferrochrome lignosulfonates}

Ferrochrome lignosulfonates is an effective dispersing agent at a high $\mathrm{pH}$ for different mud systems. It is commonly used to prevent salt flocculate of bentonite and minimize the effect of high-temperature gelatin in bentonite fluid and sometimes added to get better filtration control.

\section{Caustic soda}

Caustic soda or sodium hydroxide $(\mathrm{NaOH})$ is used in waterbased mud to raise its $\mathrm{pH}$; to solve lignite, lignosulfonate, and tannin substances; to counteract corrosion; and to neutralize hydrogen sulfide. Also, some improvement in performance can be achieved by adding caustic soda to the freshwater along with the bentonite to act as a dispersing agent.

\section{Soda ash}

The principal use of soda ash or sodium carbonate $\left(\mathrm{Na}_{2}\right.$ $\mathrm{CO}_{3}$ ) is for the removal of soluble salts from makeup of waters and muds and to enhance the yield of clay.

\section{Lime}

The function of the lime is to furnish sufficient calcium to prevent hydration and dispersion of drilled shales and clays. Lime is an inorganic compound with the chemical formula $\mathrm{Ca}(\mathrm{OH})_{2}$. It is a white powder and is derived from heating limestone (mainly calcium carbonate). This reaction produces calcium oxide (quick lime). On adding water this forms calcium hydroxide (slaked lime). Table 5 shows basic information about lime.

The environmental protection agency recognizes that lime is the most available and cost of the blending material. It does an excellent job in solidifying the particles and recommends it for use in oil field and industrial applications.

\section{Gas oil}

Gas oil is used as an oil or emulsifier to obtain a large cutting size, in addition to viscosity and fluid loss control. Table 6 shows basic information about gas oil.

\section{Core preparation}

\section{Core plugs cutting and cleaning}

In this study, the core samples were provided from seven oil wells of Zubair Formation of two oil fields in southern Iraq (Basrah region): These wells are R.45, R.99, and R.181 of Rumaila North Oil Field and Ru.64, Ru.181, Ru.182, and Ru.197 of Rumaila South Oil Field. About 100 plugs were prepared from depths of over (3000) m (pay

Table 5 Basic information of lime

\begin{tabular}{ll}
\hline Property & Value \\
\hline Sp. gr. & 2.2 \\
Molecular weight & 74.1 \\
Solubility at $100^{\circ} \mathrm{C}(\mathrm{g}$ lime $/ 100 \mathrm{~g}$ water $)$ & 0.077 \\
Solubility at $20^{\circ} \mathrm{C}(\mathrm{g}$ lime $/ 100 \mathrm{~g}$ water $)$ & 0.173 \\
\hline
\end{tabular}


Table 6 Physical properties of gas oil

\begin{tabular}{ll}
\hline Property & Value \\
\hline Sp. gr. at $24{ }^{\circ} \mathrm{C}$ & 0.825 \\
Viscosity at $19{ }^{\circ} \mathrm{C}$ (C.P.) & 4.39 \\
Viscosity at $24^{\circ} \mathrm{C}$ (C.P.) & 3.7 \\
Viscosity at $30^{\circ} \mathrm{C}$ (C.P.) & 3.3 \\
\hline
\end{tabular}

zones intervals). The core samples were cut to about one inch diameter and 1.5 inch length using a small special bit by Rockwell cutting machine. The saltwater was used as a coolant. The plugs were then cleaned using Soxhlet extraction with a mixture of equal volumes of toluene $\left(\mathrm{C}_{7} \mathrm{H}_{8}\right)$, methanol $\left(\mathrm{CH}_{3} \mathrm{OH}\right)$, and pure benzene $\left(\mathrm{C}_{6} \mathrm{H}_{6}\right)$. The process was repeated until the color of the solution no longer changes and becomes clear. After this, the plugs were dried in an oven for $24 \mathrm{~h}$ at $200^{\circ} \mathrm{F}$. A study was carried out before and after exposing the core samples to different drilling fluids. The reservoir conditions were prepared as close as possible to mimic down hole conditions, namely, hydrostatic pressure, formation pressure, and hole temperature.

\section{Permeability measurements}

Two types of permeabilities were measured by Ruska liquid permeameter:

1. Absolute permeability of formation water. Thus, all the core samples were saturated with the same fluid flow.

2. Effective permeability for gas oil was measured after measuring absolute permeability.

These two types follow Darcy's law:

$K=\frac{1000 Q \mu L}{\Delta p A}$

where $K=$ permeability of core sample (md); $Q=$ flow rate $\left(\mathrm{cm}^{3} / \mathrm{s}\right) ; \mu=$ viscosity of the liquid (cp.); $L=$ length of the core sample $(\mathrm{cm}), A=$ cross-sectional area of the core sample $\left(\mathrm{cm}^{2}\right) ; \Delta p=$ differential pressure across the core sample (atm.).

The saltwater was flushed by gas oil until the liquid flow rate through the core sample becomes constant and no more water was evident in the discharge liquid. This was done in order to reach irreducible water saturation (Swi). Gas oil was used as oil rock formations instead of other types of petroleum products. It does not volatile at room temperature, easily obtainable, and requires simple pressure to test the effective oil permeability. The effective oil permeabilities ranged from 36 to $1391 \mathrm{mD}$. This range is sufficient to give results for different experiments.

\section{Saturation measurements}

The reservoir rocks normally contain oil and water; this water is called connate water. Fluid saturation can be determined by direct method from small rock samples. The retort method had been used to determine fluid saturation. The small sample is heated to $\left(1000{ }^{\circ} \mathrm{F}\right)$ to evaporate all oil and water. The vapor is condensed and collected in small vessel after waiting for a period of $30 \mathrm{~min}$. All saturations are calculated as a percent to pore volume, according to following equations:

$\mathrm{sw}=\frac{\mathrm{WV}(\mathrm{cc})}{\mathrm{PV}(\mathrm{cc})} * 100$

So $=\frac{\mathrm{OV}(\mathrm{cc})}{\mathrm{PV}(\mathrm{cc})} * 100$

where $\mathrm{Sw}=$ water saturation $(\%)$; So = oil saturation $(\%)$; $\mathrm{WV}=$ water volume $(\mathrm{cc}) ; \mathrm{OV}=$ oil volume $(\mathrm{cc})$; $\mathrm{PV}=$ pore volume $(\mathrm{cc})$.

Saturation method had been used to measure pore volume for core samples. Formation water was used as a liquid saturation, whose density is $(1.1188 \mathrm{gm} / \mathrm{cc})$.

\section{X-ray diffraction}

X-ray diffraction analysis is that auxiliary measurement was taken in order to obtain more information of various minerals in core samples.

\section{The static immersion test}

This test measures the swelling and spalling of core sample in shale intervals due to its exposure to the different drilling fluids. The procedure test is as follows:

1. Core samples were prepared and dried in the oven at $200{ }^{\circ} \mathrm{F}$. Initial dry weights were measured.

2. Core samples immersed in two drilling muds. These muds were FCLS mud and lime mud.

3. The core samples were left static for 15 days in these muds. After period termination, the samples were collected and their final wet weight was measured.

4. The core samples were dried in the oven for $4 \mathrm{~h}$ at $200^{\circ} \mathrm{F}$. The final dry weights were measured.

5. The equations, which were used to calculate the swelling percentage and spalling percentage, are:

Swelling, wt $\%=\frac{W-W_{0}}{W_{0}}$

Spalling, wt $\%=\frac{W_{1}-W_{0}}{W_{0}}$

where $W=$ final wet weight $(\mathrm{gm}) ; W_{1}=$ initial dry weight $(\mathrm{gm}) ; W_{0}=$ final dry weight $(\mathrm{gm})$. 


\section{Experimental rig}

A laboratory rig was prepared for evaluating the extent of damage caused by drilling fluids. It consists of a core holder similar to Hassler core holder, which can accommodate a core plug of 1 inch diameter. The core holder tolerates high pressure and temperature. The core sample was placed inside a rubber sleeve and the two sealed together by overburden pressure, which applied by a hydraulic pump. The pressure of nitrogen gas was used to push the drilling fluid through the core sample at constant pressure for 1-h testing time. This pressure was considered as the differential pressure between hydrostatic and formation pressures. Figure 1 shows a schematic diagram of the Hassler core holder. The parameters that were kept constant in this study are the differential pressure (300 psi), the formation temperature $\left(200^{\circ} \mathrm{F}\right)$, and the confining pressure (5000 psi).

The other components of the rig consist of the following apparatuses:

Viscometer Viscosity of gas oil and formation water was measured by using (Ubbelhode-Holde) viscometer. It has a constant of " 0.00845 " $\mathrm{cp} / \mathrm{s}$. Viscosity is determined as the time of flow through the apparatus from the upper limit until the marked lower limit. The following equation is used to calculate viscosity.

$\mu=0.00845 * t$

where $\mu=$ dynamic viscosity (cp); $t=$ time of fluid flow (s).

Pycnometer It was used to measure the specific gravity of gas oil and formation water.

Mud Mixer Hamilton beach mixer was used in laboratory to mix the mud materials.

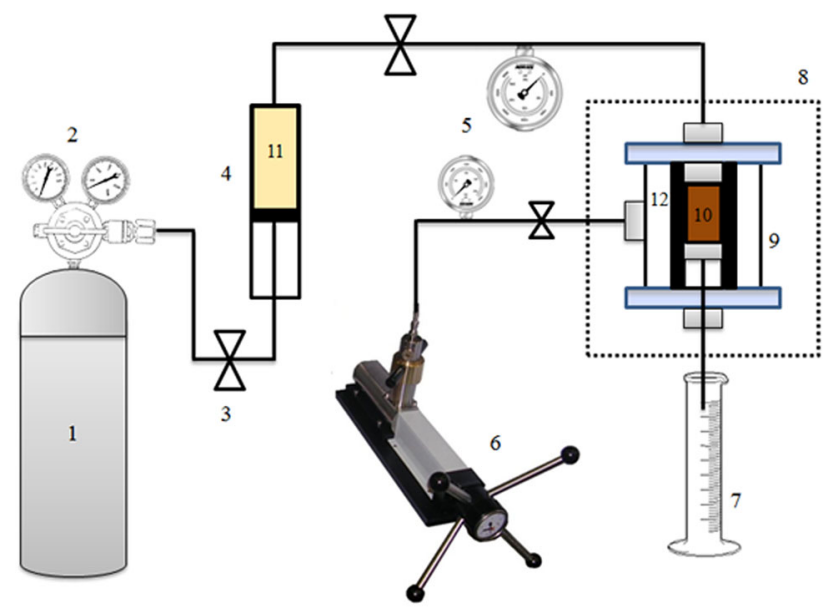

Fig. 1 Schematic diagram of the pressure core cell: $1 \mathrm{~N}_{2}$ gas cylinder, 2 gage pressure and regulator, 3 valve, 4 drilling mud container, 5 gage pressure, 6 hydraulic hand pump, 7 graduation cylinder, 8 heater jacket, 9 Hassler core holder, 10 core sample, 11 drilling mud, 12 rubber sleeve
Mud Balance Baroid mud balance was used to determine the densities of all drilling muds that were used. The mud balance may be calibrated with freshwater. The reading at room temperature should be $8.33 \mathrm{lb} / \mathrm{gal}$.

Filter Pressure Test Baroid filter press was used to determine the filtration properties of drilling muds at room temperature and 100 psi pressure at static conditions. The amount of filtrate discharged in $30 \mathrm{~min}$ is measured.

Fann V-G meter (Model 35A) was used to measure two constant speeds, $\theta 600$ and $\theta 300 \mathrm{rpm}$. The plastic viscosity (PV) is calculated by the following equation:

$\mathrm{PV}=\theta 600-\theta 300$

where PV = plastic viscosity in centipoises (cp); $\theta 600$ and $\theta 300=$ dial reading at speeds of 600 and $300 \mathrm{rpm}$, respectively.

The yield point (YP) is calculated from the following equation:

$\mathrm{YP}=\theta 300-\mathrm{PV}$

where $\mathrm{YP}=$ yield point $\left(\mathrm{lb} / 100 \mathrm{ft}^{2}\right) ; \theta 300=$ dial reading (at a speed of $300 \mathrm{rpm}$ ); PV = plastic viscosity in (cp).

Soil Hydrometer A (152 H-62 ASTM Soil Hydrometer 0-60 gm/l) was used to determine particle size distribution of muds. This test was used to calculate the diameters of particles by hydrometer analysis.

\section{Experimental procedure}

All essential calibrations for pumps, pressure gauges, and other devices were carried out before starting up any experiment. The experiments are carried out as follows:

1. The core is evacuated of air over a period of $12 \mathrm{~h}$ using a vacuum pump and then slowly saturated with $\mathrm{NaCl}$ solution (formation water) until atmospheric pressure is attained.

2. The absolute permeability is measured by the Ruska liquid permeameter with formation water.

3. The effective permeability of the core is determined by flowing gas oil at a constant pressure. Also, initial fluid saturation is determined by the direct Retort method.

4. The plug is mounted in a Hassler core holder, and the pressure is raised to the confining pressure (5000 psi).

5. The Hassler core holder is covered with a heater jacket to raise the temperature to $200{ }^{\circ} \mathrm{F}$ (reservoir formation temperature).

6. The core is damaged by a mud penetrating across its face for the duration of $1 \mathrm{~h}$ at a constant differential pressure of 300 psi using nitrogen gas pressure.

7. The sample is left for 1 day to backflow with gas oil until no further permeability is obtained. 
8. The percent of formation damage can be determined by comparison, between effective permeability and fluid saturation before and after mud exposed.

\section{Results and discussion}

Several experiments have been done to investigate the effects of drilling fluids at different concentrations of additive types (barite and gas oil) on the physical properties of muds, clay minerals existing in the core samples, and the petrophysical rock properties.

\section{Effect of gas oil and barite on physical properties of muds}

The composition and physical properties of FCLS muds and lime muds are presented in Tables 1, and 3 and 2, and 4 , respectively. All the additives of gas oil and barite changed the physical properties of muds. The inclusion of $5 \%$ by volume of gas oil to FCLS mud with $70 \mathrm{lb} / \mathrm{bbl}$ barite reduced mud filtrate from 9.6 to $7.2 \mathrm{cc}(25 \%)$ and further to $6.3 \mathrm{cc}(35 \%)$ when $10 \%$ gas oil was added, whereas the additive of $5 \%$ by volume gas oil with $140 \mathrm{lb} /$ bbl barite reduced mud filtrate from 10.5 to $7.5 \mathrm{cc}(29 \%)$. On another side, the additive of $5 \%$ by volume of gas oil to lime mud with $70 \mathrm{lb} / \mathrm{bbl}$ barite caused reduction in mud filtrate from 24 to $20 \mathrm{cc}(17 \%)$ and the additive of $10 \%$ decreases the volume to $16.5 \mathrm{cc}(31 \%)$, whereas addition of $5 \%$ by volume gas oil with $140-1 \mathrm{~b} / \mathrm{bbl}$ barite caused reduction in mud filtrate from 35 to $32 \mathrm{cc}(9 \%)$. This reduction in mud filtrate as a result of gas oil addition may be attributed to the plugging of the filter cake pores by oil droplets. These droplets are deformable, so in addition to the effect of raising the cake resistance, reducing the permeability and the filter cake becomes more compressible, and it increases the viscosity.

Barite also plays an important role in the physical properties of muds. Generally, barite additive increases the mud filtrate because of its ability to bridge filter paper and the rock formation; also it increases the mud density, mud cake thickness, and mud viscosity.

\section{Effect of drilling muds on clay minerals existing in some of the core samples}

\section{$X$-ray diffraction analyses}

This test was carried out on 12 samples taken from different intervals of some of the studied wells. A general description of mineralogy contents and depth intervals of these samples is shown in Table 7. These intervals consist of moderately to well-sorted and medium- to fine-grained sandstones. It is found that in five of the samples quartz is the main component. Table 8 shows X-ray diffraction analyses of these five samples. The other seven samples consist of some of clay minerals. Table 9 shows X-ray diffraction analyses of these seven samples.

Several treatments were applied on these samples to isolate the clay minerals. These treatments include chemical treating with ethyl glycol and heating between 350 and $550{ }^{\circ} \mathrm{C}$; the treatments were applied to separate the inclusion between X-ray peaks for clay minerals. The petrophysical properties of the seven samples, which contain clay minerals, could not be measured, because of their spalling and creaking tendencies when cut with Rockwell apparatus. For this, they were tested with static immersion tests.

Table 7 The petrographical analyses of some core samples

\begin{tabular}{lrl}
\hline $\begin{array}{l}\text { Well } \\
\text { no. }\end{array}$ & Depth (m) & General description \\
\hline R.99 & $3211-3212.5$ & Clean sandstone, medium grained, well sorted, subrounded to rounded, iron oxide (pyrite) \\
R.99 & $3188-3189$ & Sandstone, medium to fine grained, sorted, oil content, iron oxide, little amount of clay \\
R.99 & $3179-3180$ & Sandstone, dominantly medium grained, partly fine and coarse grained, clay materials, pyrite, and oil content \\
Ru.64 & $3238-3239$ & Sandstone, medium grained, well sorted, subrounded to rounded, partly coarse grained, pyrite \\
Ru.64 & $3258.5-3259$ & Sandstone, laminations of sandstone fine, medium, coarse, and very coarse grained \\
Ru.64 & $3287-3288$ & Sandstone, medium grained, sorted, the grains are oriented, compact, algid materials \\
R.45 & $3239-3240$ & Sandstone, medium grained, sorted, calcium carbonate, cemented, secondary porosity, microfractured, little amount of \\
& & clay \\
Ru.197 & $3220-3221$ & Sandstone, fine grained, well sorted, compact, calcium carbonate, cemented \\
Ru.197 & $3212-3213$ & Sandstone, dominantly medium-grained sandstone, partly fine grained, clay content (kaolinite), oil content, iron oxide \\
Ru.197 & $3271.5-3272$ & Sandstone, fine to medium grained, calcium carbonate, secondary porosity \\
Ru.181 & $3287.5-3288.5$ & Sandstone, medium to coarse grained, porosity full partly by algid materials \\
Ru.181 & $3210-3211.5$ & Sandstone, medium grained, sorted, calcium carbonate, cemented, oil content
\end{tabular}


Table 8 Results of X-ray analysis of clean formations

\begin{tabular}{|c|c|c|c|c|c|}
\hline \multirow{2}{*}{$\begin{array}{l}\text { Well no. } \\
\text { Sample no. }\end{array}$} & \multirow{2}{*}{$\begin{array}{l}\text { R.99 } \\
1\end{array}$} & \multicolumn{2}{|l|}{ Ru.182 } & \multirow{2}{*}{$\begin{array}{l}\text { Ru.197 } \\
4\end{array}$} & \multirow{2}{*}{$\begin{array}{l}\text { R. } 45 \\
5\end{array}$} \\
\hline & & 2 & 3 & & \\
\hline Depth (m) & $3211-3212.5$ & 3386.8 & 3381.8 & $3212-3213$ & $3239-3240$ \\
\hline \multicolumn{6}{|l|}{ Mineral type } \\
\hline Quartz & 99 & 97.63 & 96.71 & 94.56 & 95.97 \\
\hline Calcite & - & - & - & 1.89 & - \\
\hline Feldspar & - & 1.25 & 1.64 & 1.36 & - \\
\hline Other minerals & 1 & - & - & - & - \\
\hline \multicolumn{6}{|l|}{ Clay minerals } \\
\hline Kaolinite & - & 1.12 & 1.65 & 2.19 & - \\
\hline Illite & - & - & - & - & - \\
\hline Montmorillonite & - & - & - & - & - \\
\hline Chlorite & - & - & - & - & 4.03 \\
\hline Total & 100.0 & 100.0 & 100.0 & 100.0 & 100.0 \\
\hline
\end{tabular}

Table 9 Results of X-ray analysis of dirty formations

\begin{tabular}{|c|c|c|c|c|c|c|c|}
\hline \multirow{2}{*}{$\begin{array}{l}\text { Well no. } \\
\text { Sample no. }\end{array}$} & \multicolumn{4}{|c|}{ Ru.197 } & \multicolumn{3}{|l|}{ R.181 } \\
\hline & 6 & 7 & 8 & 9 & 10 & 11 & 12 \\
\hline Depth (m) & 3201 & 3216 & 3229 & 3247 & 3205 & 3225 & 3240 \\
\hline \multicolumn{8}{|l|}{ Mineral type } \\
\hline Quartz & 71.16 & 77.82 & 73.28 & 74.32 & 92.8 & 94 & 95.7 \\
\hline Calcite & 12.73 & 6.22 & 4.4 & 4.41 & - & - & - \\
\hline Feldspar & 10.48 & 6.63 & 5.11 & 6.4 & 1.43 & 0.85 & 1.17 \\
\hline \multicolumn{8}{|l|}{ Clay minerals } \\
\hline Kaolinite & 2.67 & 2.94 & 7.82 & 6.11 & 1.17 & 1.05 & 0.43 \\
\hline Illite & 1.83 & 3.28 & 4.30 & 3.96 & 1.36 & 0.7 & Trace \\
\hline Montmorillonite & 1.13 & 3.11 & 5.09 & 4.8 & 3.24 & 3.44 & 2.7 \\
\hline Total & 100.0 & 100.0 & 100.0 & 100.0 & 100.0 & 100.0 & 100.0 \\
\hline
\end{tabular}

\section{The static immersion test}

This test was applied to various core samples, especially those which contain clay minerals (shale intervals). The purpose of this test was to evaluate the swelling and spalling that may occur in various core samples when exposed to drilling fluids. This test is very important because the damage zones interbedded with pay zones and any damage in them may cause partial or total damage to the well or may affect it. This test was applied on FCLS mud and Lime mud with a barite content of $70 \mathrm{lb} / \mathrm{bbl}$ and with no gas oil additive.

Clay swelling has been regarded as one of the major causes for formation damage in hydrocarbon reservoirs. Thus, X-ray diffraction method is introduced for its study. The results indicated that the drilling fluids have different effects on core samples and the effects depend on the amounts of clay minerals in the samples, especially illite and montmorillonite minerals.

Eight core samples from three wells were subjected to the FCLS mud and lime mud. These samples can be divided into three groups according to X-ray diffraction analyses, clean, moderate, and dirty samples. The X-ray diffraction analyses indicated that the fluids have very little effect on the clean samples. This may be noticed clearly in Figs. 2 and 3, core no. (2). The second group contains some amounts of clay minerals, core no. (10, 11, and 12), affected by FCLS mud which caused swelling and spalling more than the first group. The third group contains a high percent of clay minerals, and this is noticed in sample nos. $(6,7,8$, and 9) which caused higher swelling and spalling due to high mud interaction. Also, the results show that the swelling percentage was less using lime mud compared with the FCLS mud. This may be because the presence of 
Fig. 2 The swelling (\%) of different core samples due to FCLS and lime muds

Fig. 3 The spalling (\%) of different core samples due to FCLS and lime muds
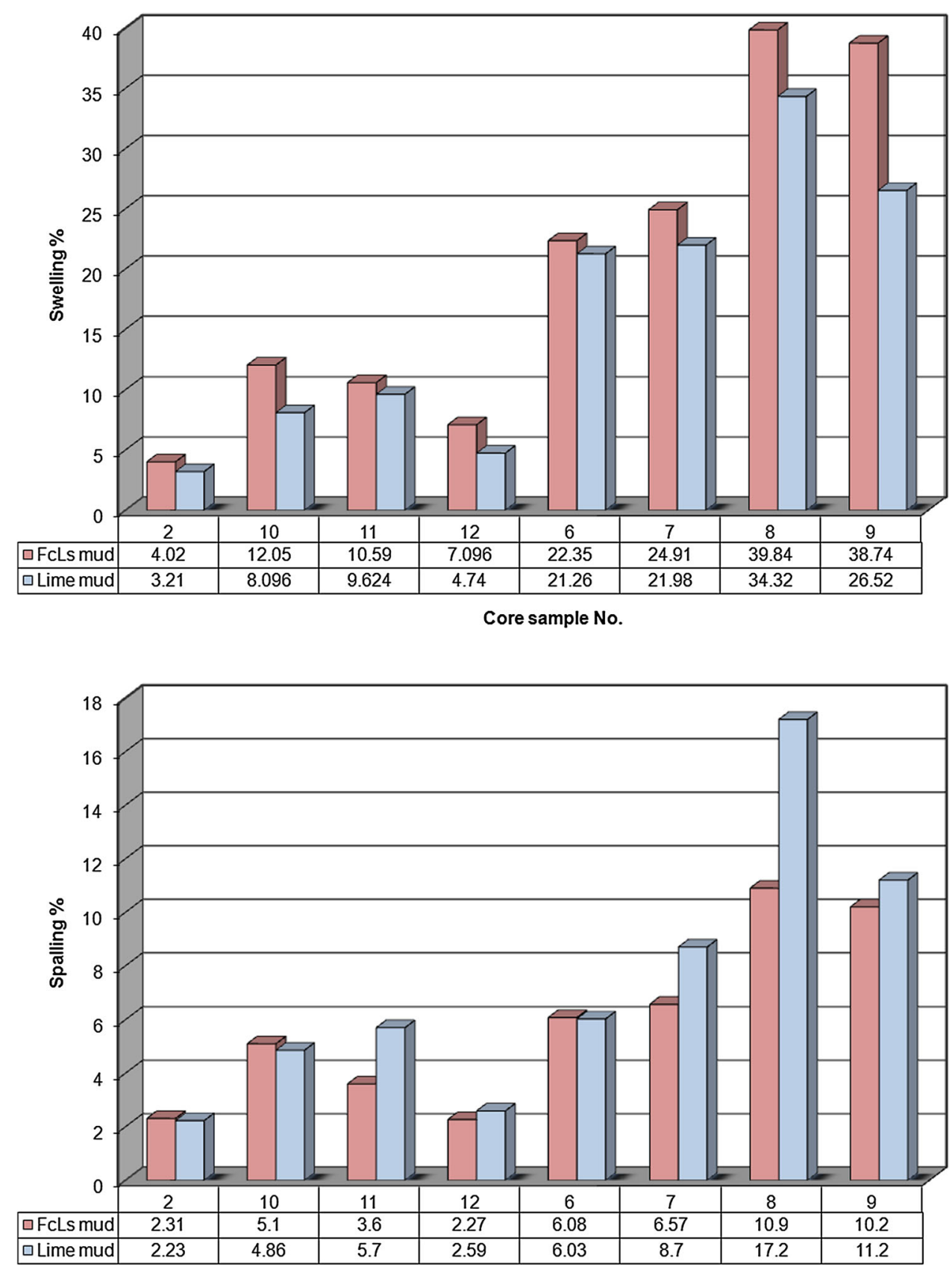

Core sample No. calcium cations in the lime mud has the ability to reduce the swelling of shale. Finally, the results show that the spalling percentage is high using lime mud compared with the FCLS mud because the lime mud has a high volume of filter loss due to lowering of adsorbed water by calciumbased clay, and this makes the particles tend to spall.

\section{Effect of drilling fluids on the petrophysical characteristics}

The core samples are exposed to various combinations of drilling muds to study their effect on the petrophysical properties such as effective permeability and fluid saturation.

\section{Effect of gas oil additive}

Table 10 gives the effect of gas oil additives to (FCLS) drilling fluid on the effective oil permeability (Ko) and water saturation (Swi) of the core samples. When no gas oil was added, a high damage in (Ko) is noticed. It ranges from 27 to $57 \%$ for different values of permeabilities. Also, changes in water saturations are observed. The water saturations increased from 21 to $64 \%$ due to invasion of mud 
Table 10 Effect of gas oil and barite FCLS mud additives on permeability and saturation of core samples

\begin{tabular}{|c|c|c|c|c|c|c|}
\hline Adding $\%$ & Ko (md) & Swi \% & $\mathrm{Kd}(\mathrm{md})$ & Swr \% & $\mathrm{Kd} \%$ & Swd \% \\
\hline \multirow[t]{8}{*}{$0 \%$ gas oil and $70 \mathrm{ppg}$ barite } & 41.50 & 36.70 & 17.80 & 60.18 & 57.11 & 63.98 \\
\hline & 82.00 & 30.80 & 40.94 & 49.06 & 50.07 & 59.29 \\
\hline & 130.00 & 36.80 & 66.60 & 51.88 & 48.77 & 40.98 \\
\hline & 255.00 & 28.65 & 155.04 & 38.24 & 39.20 & 33.47 \\
\hline & 350.00 & 27.27 & 217.10 & 36.35 & 37.97 & 33.30 \\
\hline & 427.00 & 24.00 & 284.00 & 29.52 & 33.49 & 23.00 \\
\hline & 568.00 & 18.90 & 399.00 & 22.90 & 29.75 & 21.16 \\
\hline & 1202.00 & 17.30 & 880.00 & 21.00 & 26.79 & 21.39 \\
\hline \multirow[t]{4}{*}{$5 \%$ gas oil and 70 ppg barite } & 46.00 & 34.00 & 26.00 & 47.91 & 43.48 & 40.91 \\
\hline & 157.31 & 26.00 & 92.00 & 35.39 & 41.52 & 36.12 \\
\hline & 329.80 & 25.00 & 220.00 & 32.00 & 33.29 & 28.00 \\
\hline & 1126.60 & 16.10 & 859.40 & 19.40 & 23.72 & 20.50 \\
\hline \multirow[t]{4}{*}{$10 \%$ gas oil and 70 ppg barite } & 39.00 & 38.00 & 29.00 & 53.13 & 25.64 & 39.82 \\
\hline & 167.65 & 27.00 & 128.33 & 33.36 & 23.45 & 23.56 \\
\hline & 298.41 & 27.15 & 230.23 & 33.10 & 22.85 & 21.92 \\
\hline & 1319.80 & 18.20 & 1089.30 & 21.22 & 17.46 & 16.59 \\
\hline \multirow[t]{5}{*}{$0 \%$ gas oil and $140 \mathrm{ppg}$ barite } & 50.00 & 33.00 & 15.00 & 47.00 & 70.00 & 42.42 \\
\hline & 84.50 & 32.00 & 33.00 & 42.75 & 60.95 & 33.59 \\
\hline & 189.50 & 27.30 & 98.00 & 35.92 & 48.28 & 31.58 \\
\hline & 389.40 & 25.20 & 273.60 & 32.50 & 29.74 & 28.97 \\
\hline & 448.00 & 23.10 & 343.40 & 27.58 & 23.35 & 19.39 \\
\hline \multirow[t]{4}{*}{$5 \%$ gas oil and $140 \mathrm{lb} / \mathrm{bbl}$ barite } & 47.00 & 38.20 & 33.00 & 51.14 & 29.79 & 33.87 \\
\hline & 167.87 & 29.30 & 123.90 & 38.47 & 26.19 & 31.30 \\
\hline & 284.00 & 28.90 & 217.54 & 37.25 & 23.40 & 28.89 \\
\hline & 531.18 & 20.00 & 422.65 & 23.56 & 20.43 & 17.80 \\
\hline
\end{tabular}

filtrate. It is found that when $5 \%$ gas oil was added to the drilling fluid, there are upgrades in permeability and water saturation values of the damaged samples. Maximum return in permeability and water saturation is achieved when $10 \%$ gas oil was added. An improvement in damage permeability (Kd) \% values ranges from 17 to $26 \%$, while improvement in water saturation ranged from 17 to $40 \%$ of the damage samples without gas oil additive. Similar observation is noticed when gas oil was added to the lime mud. Table 11 gives the effect of gas oil additive to the lime mud.

The results indicate that gas oil makes reductions in mud filter loss, in addition to reduce the damage permeability (Kd) and saturation change. Also, the percentage of damage permeability increased as effective oil permeability (Ko) values decrease. Finally, lime mud shows less effect than FCLS mud on the petrophysical properties of the core samples and $10 \%$ gas oil additive reduced the damage to minimum values.

\section{Effect of barite additive}

Table 10 shows the damage in oil permeability and the increase in water saturation when exposed to the core samples to FCLS drilling mud. At fixed gas oil additive of $5 \%$, a 70 and $140 \mathrm{lb} / \mathrm{bbl}$ of barite were added to the FCLS mud in order to study the barite effect on the core samples and the drilling mud properties. It is found that the mud with $70 \mathrm{lb} / \mathrm{bbl}$ of barite caused more damage than the mud with additive of $140 \mathrm{lb} / \mathrm{bbl}$. The damaged permeability percent $(\mathrm{Kd} \%)$ ranges from 24 to $43 \%$ and from 20 to $30 \%$ with additive of 70 and $140 \mathrm{lb} / \mathrm{bbl}$ of barite, respectively. Also, the water saturations for different core samples decreased with barite additive. The saturation reduction (Swd \%) ranged from 21 to $41 \%$ with $70 \mathrm{lb} / \mathrm{bbl}$, while from 18 to $34 \%$ for the mud with additive of $140 \mathrm{lb} /$ bbl of barite from the original value.

Table 11 presents the exposure of core samples to lime muds; it shows that the mud with $70 \mathrm{lb} / \mathrm{bbl}$ of barite 
Table 11 Effect of gas oil and barite lime mud additives on permeability and saturation of core samples

\begin{tabular}{|c|c|c|c|c|c|c|}
\hline Adding \% & Ko (md) & Swi $\%$ & $\mathrm{Kd}(\mathrm{md})$ & Swr \% & $\mathrm{Kd} \%$ & Swd \% \\
\hline \multirow[t]{4}{*}{$0 \%$ gas oil and $70 \mathrm{ppg}$ barite } & 35.89 & 38.30 & 23.97 & 52.73 & 33.21 & 37.68 \\
\hline & 171.88 & 28.50 & 130.37 & 38.87 & 24.15 & 36.39 \\
\hline & 375.85 & 23.40 & 313.08 & 29.60 & 16.70 & 26.50 \\
\hline & 463.00 & 20.78 & 410.68 & 24.68 & 11.30 & 18.77 \\
\hline \multirow[t]{4}{*}{$5 \%$ gas oil and 70 ppg barite } & 48.23 & 36.00 & 34.80 & 47.00 & 27.85 & 30.56 \\
\hline & 89.50 & 33.00 & 68.64 & 43.00 & 23.31 & 30.30 \\
\hline & 187.29 & 27.30 & 154.20 & 33.00 & 17.67 & 20.88 \\
\hline & 427.39 & 21.60 & 385.40 & 26.48 & 9.82 & 22.59 \\
\hline \multirow[t]{4}{*}{$10 \%$ gas oil and 70 ppg barite } & 34.29 & 39.00 & 28.70 & 47.62 & 16.30 & 22.10 \\
\hline & 103.25 & 30.70 & 86.73 & 37.20 & 16.00 & 21.17 \\
\hline & 235.42 & 25.00 & 199.75 & 29.37 & 15.15 & 17.48 \\
\hline & 521.12 & 18.42 & 489.30 & 21.38 & 6.11 & 16.07 \\
\hline \multirow[t]{4}{*}{$0 \%$ gas oil and $140 \mathrm{ppg}$ barite } & 41.3 & 36.6 & 29.488 & 50.83 & 28.6 & 38.9 \\
\hline & 186.56 & 28.12 & 147.94 & 35.43 & 20.7 & 26 \\
\hline & 375 & 22.7 & 313.87 & 28.08 & 16.3 & 23.7 \\
\hline & 445.2 & 21 & 391.776 & 24.89 & 12 & 18.56 \\
\hline \multirow[t]{4}{*}{$5 \%$ gas oil and 140 ppg barite } & 44 & 38 & 49.50 & 52 & 22.3 & 30.26 \\
\hline & 185.16 & 26.7 & 158.86 & 33 & 14.2 & 23.59 \\
\hline & 264.3 & 23 & 230.2 & 27.69 & 12.9 & 20.43 \\
\hline & 527.88 & 21.8 & 486.7 & 25.04 & 7.8 & 14.9 \\
\hline
\end{tabular}

Table 12 Types of particle size percents of different barite added to mud according to ASTM

\begin{tabular}{lllll}
\hline Sample no. & Barite content ppb. & Clay \% 2 greater than microns & Silt \% 2-75 microns & Sand \% 75 less than microns \\
\hline 1 & 0 & 77 & 23 & 0 \\
2 & 32 & 27 & 68 & 0 \\
3 & 140 & 73 & 0 & 0 \\
\hline
\end{tabular}

additive caused more damage than $140 \mathrm{lb} / \mathrm{bbl}$ of barite additive. The permeability damage percent $(\mathrm{Kd} \%)$ ranges from 10 to $28 \%$ with $70 \mathrm{lb} / \mathrm{bbl}$ of barite and from 8 to $22 \%$ with additive of $140 \mathrm{lb} / \mathrm{bbl}$. Also, water saturation showed a lower increase with additive of $70 \mathrm{lb} / \mathrm{bbl}$ of barite compared with $140 \mathrm{lb} / \mathrm{bbl}$ of barite. Water saturation ranges from 21 to $31 \%$ with $70 \mathrm{lb} / \mathrm{bbl}$ of barite and from 15 to $30 \%$ with $140 \mathrm{lb} / \mathrm{bbl}$ of barite. This behavior is found to be the same irrespective of the $5 \%$ of gas oil additive.

The water saturation increased due to the penetration of water and the colloidal materials into the core samples; however, much of this water can be removed by oil backflow but with colloidal materials the operation seems to be less. The particle size distributions of colloidal particles have a large percent and reach about $77 \%$ as shown in Table 12. The colloidal particles cause high permeability impairment because of its ability to pass through the core pores. Table 12 also shows that barite is composed of particles in the 2- to $75-\mu \mathrm{m}$ size range, and this can make quick bridging for all formations of permeability less than about one Darcy (Abrams 1977).
When no additive of gas oil and 70 and $140 \mathrm{lb} / \mathrm{bbl}$ of barite were added to the FCLS and lime muds, it is found that the barite did not make more reduction in the damage of the petrophysical properties.

Generally, lime muds caused little damage compared with FCLS muds because of its ability to inhibit and control shale swelling.

\section{Conclusions}

The conclusions drawn below are constructed depending on the samples used in this study:

1. The swelling percentage is less using lime mud compared with the FCLS mud. This may be because the presence of calcium cations in the lime mud has the ability to reduce the swelling of shale. Also, the spalling percentage is high using lime mud compared with the FCLS mud because the lime mud has a high volume of filter loss due to lowering of adsorbed water 
by calcium-based clay, and this makes the particles tend to spall.

2. Lime mud has the capability of reducing clay swelling approximately $20 \%$ of FCLS mud in shale intervals because lime mud is primarily used for drilling shale and clay formations which do not cause much formation alteration.

3. Gas oil addition causes reduction in mud filtrate due to the formation of impermeable mud cake on the face of the filter paper or on the face of core samples because of their high solid tolerance which suspends solid material.

4. Adding a combination of barite and gas oil to drilling muds could make a better reduction in damage of the petrophysical properties. These additives are particularly contributions in drilling production zones, shales, and other water-sensitive formations, as clays do not hydrate or swell in gas oil.

Acknowledgments This work was supported by the University of Baghdad, Petroleum Engineering Department, which is gratefully acknowledged. Also, the authors gratefully acknowledge the help rendered by the team of State Company of Geological Survey and Mining, Baghdad, State Company of Oil Discovery, Baghdad, South Oil Company, Basrah, Iraq, for providing the materials and information.

Open Access This article is distributed under the terms of the Creative Commons Attribution 4.0 International License (http:// creativecommons.org/licenses/by/4.0/), which permits unrestricted use, distribution, and reproduction in any medium, provided you give appropriate credit to the original author(s) and the source, provide a link to the Creative Commons license, and indicate if changes were made.

\section{References}

Abdou MI, Al-Sabagh AM, Dardir MM (2013) Evaluation of Egyptian bentonite and nano-bentonite as drilling mud. Egypt $\mathrm{J}$ Pet 22:53-59
Abrams A (1977) Mud design to minimize rock impairment due to particle invasion. JPT 29(05):586-592

Al-Ameri TK, Pitman J, Naser ME, Zumberge J, Al-Haydari HA (2011) Programed oil generation of the Zubair Formation, Southern Iraq oil fields: results from Petromod software modeling and geochemical analysis. Arab J Geosci 4:1239-1259

Al-Hitti AH, Al-Assaf SA, Ibrahim DS (2005) Reduction of formation damage due to drilling muds. J Eng 11:21-32

Bennion DB, Thomas FB, Bennion DW, Bietz RF (1995) Mechanisms of formation damage and permeability impairment associated with the drilling, completion and production of low API gravity oil reservoirs. SPE 30320:689-707

Bennion DB, Thomas FB, Jamaluddin AKM, Ma T, Agnew C (1997) Formation damage and reservoir considerations for overbalanced and underbalanced CT operations. In: Prepared for presentation at the 6th international conference on coiled tubing technologies to be held. Houston, pp 27-29

Blkoor SO, Fattah KA (2013) The influence of XC-polymer on drilling fluid filter cake properties and formation damage. J Pet Environ Biotechnol 4:1-10

Dabiri A, Afkhami M, Fallah H (2013) Reservoir formation damage due to mud filtration. AJCHE 1:1-5

Darley HCH, Gray GR (1988) Composition and properties of drilling and completion fluids, 5th edn. Gulf Publishing Company, Houston

Falkowicz S, Kapusta P (2002) Biological control of formation damage. SPE 73792:1-6

Glenn EE, Slusser ML, Huitt JL (1957) Factors affecting well productivity, I. Drilling fluid filtration. AIME 210:126-131

Hodge RM, Augustine BG, Burton RC, Sanders WW (1997) Evaluation and selection of drill-in-fluid candidates to minimize formation damage. SPE 31082:174-179

Longeron D, Argillier J, Audibert A (1995) An integrated experimental approach for evaluating formation damage due to drilling and completion fluids. SPE 30089:117-131

Sönmez A, Versan Kök M, Özel R (2013) Performance analysis of drilling fluid liquid lubricants. J Pet Sci Eng 108:64-73

Ventresca ML, Betancourt J, Castillo J, Ciguela J, Azuaje C (1995) Chemical system for treating formation damage induced by inverted oil muds. SPE 30125:479-488

Warren B, King K, Browne G, Mann C (2001) Preventing formation impairment with a MicronAire ${ }^{\mathrm{TM}}$ drilling fluid system. In: Proceedings of the national drilling technical Conference AADE, 01-NC-HO-49, pp 1-10

Windarto, Gunawan AY, Sukarno P, Soewono E (2012) Modelling of formation damage due to mud filtrate invasion in a radial flow system. J Pet Sci Eng 100:99-105 